\title{
OPTIMIZATION OF DIAMOND CORE BIT PERFORMANCE UTILIZING HIGH ROTARY SPEED IN DRILLING LIMESTONE ROCKS
}

\author{
Mohamed A. Sayed ${ }^{1}$ and Gamal Y. Boghdady ${ }^{2}$ \\ ${ }^{I}$ Professor at the Mining and Metallurgical Engineering Department, \\ E-mailmohamad_sayed2007@yahoo.com \\ ${ }^{2}$ Lecturer at the Mining and Metallurgical Engineering Department, \\ E-mailgamal_64@hotmail.com \\ Faculty of Engineering, Assiut University, Assiut 71516, Egypt
}

(Received August 11, 2010 Accepted September 20, 2010)

The principal factors that require in predicting drilling rates are the operating parameters of the drill bits and the penetrated rock characteristics. The effect of some mechanical and geological parameters on the penetration rate during drilling limestone rocks has been previously carried out by using a low rotary speed of $400 \mathrm{rpm}$. In this work, the drilling trails were carried out on the same rocks and by using the same machine and bit at high rotary speed of approximately 1200 rpm.

A fixed laboratory-diamond drilling machine was used to drill three types of limestone rocks utilizing rotational speed of $1200 \mathrm{rpm}$, and over a range of weights on bit (WOB). Operating parameters of the drill bit such as $W O B$, rate of penetration (ROP), torque and drilling specific energy $(S E)$ were continuously monitored during the drilling trials. The effects of these parameters on the performance of the bit were examined. Relationships between WOB and both ROP, and SE were also described and the relationship between ROP and SE was also given. The obtained results were compared with that obtained by using a low rotary speed of $400 \mathrm{rpm}$. Increasing the rotary speed from $400 \mathrm{rpm}$ to $1200 \mathrm{rpm}$ increases the rate of penetration 3 times for Fresh limestone at the optimum weight on bit of $105 \mathrm{~kg}$ and this leads to decrease the specific energy. To obtain ROP of $0.5 \mathrm{~cm} / \mathrm{min}$ as an example, the drilling machine needs S.E in NonFresh Limestone 3 times that for Fresh limestone and 2 times for Bedded limestone.

\section{INTRODUCTION}

Drilling is an essential and integral process of mineral exploration to present a clear picture of extent of any ore body, its mineral content, the stratigraphy or to confirm any geological or indirect geological interpretations of what is lying below the earth's surface. The type of strata and structure to be drilled has a significant influence on the drilling performance of a bit. Resistance to penetration, resistance to shearing action of the bit in rotation and the degree of abrasiveness are the properties that would be expected to have the greatest influences $[1,2]$. 
The overall performance of any drill bit is complex and is affected by numerous factors which include operating parameters of the bit, formation properties, bit design and type, wear characteristics, drilling fluid properties and flow mechanics, hole characteristics, capacity of the drilling machine, time, climate and operator or crew efficiency. [3,4]

The effect of some mechanical and geological parameters on the penetration rate during drilling limestone rocks has been previously carried out by using a low rotary speed of $400 \mathrm{rpm}$ [5]. In this work, the drilling trails were carried out on the same rocks and by using the same machine and bit at high rotary speed of approximately $1200 \mathrm{rpm}$.

The same diamond drilling machine was used to obtain cores from the same three types of limestone formation of different properties. The three types of rock were obtained from the Assiut cement company quarries, Egypt. The inside diameter of the bit used is $40 \mathrm{~mm}$ and the outside is $45 \mathrm{~mm}$ and the bit has four water way. Therefore, the bit has a set of drilling data for the rocks, at a particular rpm and applied weight on bit. A total of 75 drilling tests have been completed and a total of $6 \mathrm{~m}$ has been drilled. $[5,6]$

Geological difficulties may have a high impact on the economics of underground construction project, especially when the chosen excavation system turns out to be unsuitable for the conditions encountered. Thus it can be argued that the geological and petrological characteristics of the rock mass should be evaluated with the same degree of effort as that for the geotechnical prognosis.[7,8]

PDC drill bit performance has been greatly improved over the past three decades by innovations in bit design and how these designs are applied [9]. Diamond bit drilling is one of the most widely used and preferable drilling techniques because of its higher rate of penetration and core recovery in the hardest rocks, the ability to drill in any direction with less deviation, and the ability to drill with greater precision in coring and prospecting drilling [10]

The goal of this work is to optimize the performance of diamond core bit in limestone formation with degrees of hardness at high rotary speed.

\section{PROPERTIES OF THE TESTED ROCKS}

Three types from limestone \{fresh limestone (rock No.1), bedded limestone (rock No.2) and non fresh limestone (rock No.3) \} were collected from the quarry of Assiut Cement Company (cemex) Fig. ( 1 ).

It is clear, that the drilling parameters and tool wear are predominantly a result of the mineral content harder than steel, especially quartz, calcite, iron oxide, and the orientation of the bedding which affected in the rate of penetration [11].

Operating elements of drilling tools and machines in contact with rocks are exposed not only to mechanical stress but also to the friction between the surface of operating elements and rocks [12].

The most important physical and mechanical properties of the tested rocks such as density, porosity, compressive strength, tensile strength, and coefficient of internal friction $(\mu)$ were previously determined. Table (1) contains the average value for each respective test together with its stander deviation. The rocks were chosen as a testing medium because they represent a range of rocks, in terms of strength, for 
mining and civil engineering. The data of drilling trials were carried out at drilling speed of $400 \mathrm{rpm}$ represented in Table (2) [5].

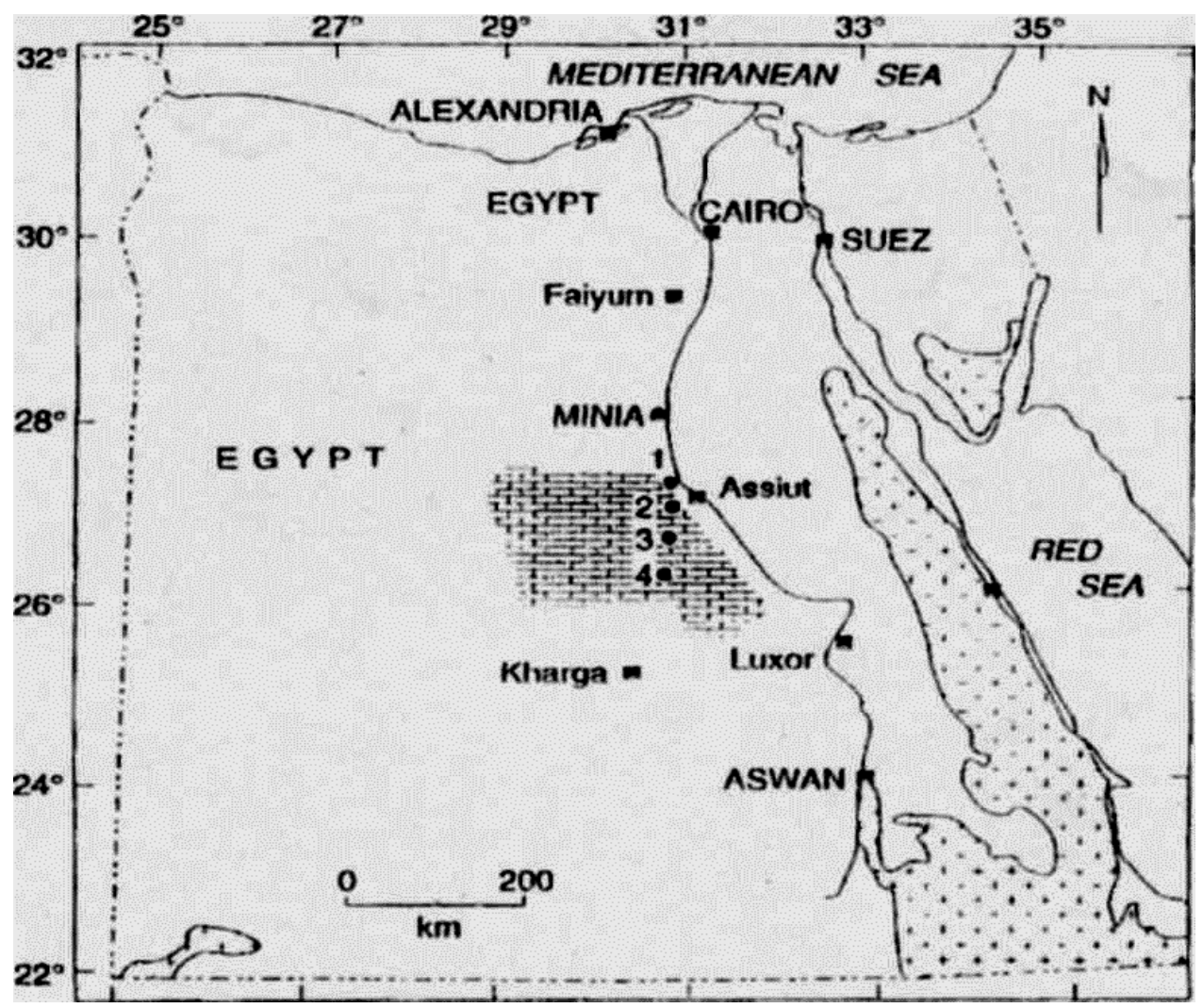

Fig.1. showing the location map of study area

Table (1): The final values of physical and mechanical properties of the tested rocks

\begin{tabular}{|c|c|c|c|c|c|}
\hline $\begin{array}{c}\text { Rock } \\
\text { type }\end{array}$ & $\begin{array}{c}\text { Compressive } \\
\text { strength, } \\
\text { MPa }\end{array}$ & $\begin{array}{c}\text { Tensile } \\
\text { strength, } \\
\text { MPa }\end{array}$ & $\begin{array}{c}\text { Density, } \\
\text { g/cc }\end{array}$ & $\begin{array}{c}\text { Porosity, } \\
\text { \% }\end{array}$ & $\begin{array}{c}\text { Coefficient } \\
\text { of friction. }\end{array}$ \\
\hline Rock 1 & $137.8 \pm 11.57$ & $17.14 \pm 1.2$ & $2.06 \pm 0.032$ & $12.87 \pm 0.94$ & 0.95 \\
\hline Rock 2 & $271.82 \pm 9.97$ & $36.4 \pm 0.66$ & $2.30 \pm 0.030$ & $9.06 .1 \pm 0.72$ & 1.02 \\
\hline Rock 3. & $259.01 \pm 15.1$ & $27.41 \pm 1.79$ & $2.42 \pm 0.009$ & $6.83 \pm 0.21$ & 1.03 \\
\hline
\end{tabular}

\section{EXPERIMENTAL WORK}

In the present study, blocks are formed by diamond saw from each type of rock for the drilling test. Diamond core drilling is applied for the tests. The coring bit used has thin walled impregnated diamond type, inner diameter $40 \mathrm{~mm}$ and the outer one $45 \mathrm{~mm}$. The drilling machine is a fixed laboratory type [13]. 
Table (2): Experimental data for the operating parameters of the core drilling at $400 \mathrm{rpm}$.

\begin{tabular}{|c|c|c|c|c|c|c|c|c|c|}
\hline \multirow{2}{*}{$\begin{array}{c}\text { WOB, } \\
\text { Kg }\end{array}$} & \multicolumn{2}{|c|}{ Fresh limestone (Rock1) } & \multicolumn{2}{c|}{ Bedded limestone (Rock 2) } & \multicolumn{2}{c|}{ Non fresh limestone (Rock 3) } \\
\cline { 2 - 10 } & $\begin{array}{c}\text { ROP, } \\
\mathrm{mm} / \mathrm{min}\end{array}$ & $\begin{array}{c}\text { Torque, } \\
\mathrm{Nm}\end{array}$ & $\begin{array}{c}\text { SE, } \\
\mathrm{MPa}\end{array}$ & $\begin{array}{c}\text { ROP, } \\
\mathrm{mm} / \mathrm{min}\end{array}$ & $\begin{array}{c}\text { Torque, } \\
\mathrm{Nm}\end{array}$ & $\begin{array}{c}\text { SE } \\
\mathrm{MPa}\end{array}$ & $\begin{array}{c}\text { ROP, } \\
\mathrm{mm} / \mathrm{min}\end{array}$ & $\begin{array}{c}\text { Torque, } \\
\text { Nm }\end{array}$ & $\begin{array}{c}\text { SE, } \\
\mathrm{MPa}\end{array}$ \\
\hline 15 & 0.14 & 3.17 & 3576.58 & - & - & - & - & - & - \\
\hline 30 & 2.07 & 6.34 & 483.677 & - & - & - & 0.0895 & 6.88 & 12139.54 \\
\hline 45 & 2.58 & 9.51 & 582.100 & 0.30 & 10.21 & 5374.54 & 0.152 & 10.31 & 10711.55 \\
\hline 60 & 3.2 & 12.68 & 625.758 & 0.50 & 13.62 & 4301.74 & 0.218 & 13.75 & 9960.55 \\
\hline 75 & 2.5 & 15.85 & 1001.21 & 0.52 & 17.02 & 5168.84 & 0.2905 & 17.19 & 9344.73 \\
\hline 90 & 2.5 & 19.02 & 1201.46 & 0.72 & 20.43 & 4480.98 & 0.492 & 20.63 & 6621.73 \\
\hline 105 & 1.9 & 22.19 & 1844.33 & 0.75 & 23.83 & 4807.08 & 0.6063 & 24.06 & 6266.79 \\
\hline 120 & - & - & - & 0.95 & 27.23 & 4526.49 & 0.7408 & 27.50 & 5862.31 \\
\hline 135 & - & - & - & 0.85 & 30.64 & 5692.55 & 0.5966 & 30.94 & 8189.82 \\
\hline 150 & - & - & - & - & - & - & 0.7378 & 34.37 & 7356.61 \\
\hline
\end{tabular}

Data and conditions of drilling experiments and rock under tests were recorded. Applied load, actual speed, length of borehole, time of drilling are recorded as results of drilling. This result is used to calculate the drilling rate, and the average drilling rate at specific load. Three trials were carried out for a particular weight on bit (WOB). Selection of the WOB range for the bit was made by applying minimum WOB where the bit was just capable of drilling the rock and maximum WOB just below the point where the drill commenced to stall or showed "distressed" drilling. Ten WOB increments for each rock were selected between this limit [5].

All drilling trials were carried out at drilling speed of $1200 \mathrm{rpm}$ motor speed. The experimental data of the operating parameters are presented in Table (3).

Table (3) - Experimental data for the operating parameters of the core drilling at $(1200 \mathrm{rpm})$.

\begin{tabular}{|c|c|c|c|c|c|c|c|c|c|}
\hline \multirow{2}{*}{$\begin{array}{c}\text { WOB, } \\
\mathrm{Kg}\end{array}$} & \multicolumn{2}{|c|}{ Fresh limestone( Rock1) } & \multicolumn{3}{c|}{ Bedded limestone( Rock2) } & \multicolumn{3}{c|}{ Non fresh limestone( Rock3) } \\
\cline { 2 - 11 } & $\begin{array}{c}\text { ROP, } \\
\mathrm{cm} / \mathrm{min}\end{array}$ & $\begin{array}{c}\text { Torque, } \\
\mathrm{Nm}\end{array}$ & $\begin{array}{c}\mathrm{SE}, \\
\mathrm{MPa}\end{array}$ & $\begin{array}{c}\text { ROP, } \\
\mathrm{cm} / \mathrm{min}\end{array}$ & $\begin{array}{c}\text { Torque, } \\
\text { Nm }\end{array}$ & $\begin{array}{c}\text { SE, } \\
\mathrm{MPa}\end{array}$ & $\begin{array}{c}\text { ROP, } \\
\mathrm{cm} / \mathrm{min}\end{array}$ & $\begin{array}{c}\text { Torque, } \\
\text { Nm }\end{array}$ & $\begin{array}{c}\text { SE, } \\
\text { MPa }\end{array}$ \\
\hline 30 & 2.5 & 6.34 & 1201.45 & 1.12 & 6.81 & 2880.63 & - & - & - \\
\hline 45 & 3.6 & 9.51 & 1251.52 & 1.60 & 10.21 & 3023.18 & - & - & - \\
\hline 60 & 4.5 & 12.68 & 1224.95 & 1.63 & 13.62 & 3958.65 & 0.2923 & 13.75 & 22462.75 \\
\hline 75 & 6.0 & 15.85 & 1251.52 & 2.09 & 17.02 & 3858.08 & 0.36921 & 17.19 & 22622.04 \\
\hline 90 & 8.1 & 19.02 & 1112.45 & 1.81 & 20.43 & 5347.47 & 0.5126 & 20.63 & 19164.05 \\
\hline 105 & 10.8 & 22.19 & 973.40 & 1.66 & 23.83 & 6801.02 & 0.756 & 24.06 & 14998.24 \\
\hline 120 & 14.2 & 25.365 & 846.26 & - & - & - & 1.7925 & 27.50 & 7278.43 \\
\hline 135 & - & - & - & - & - & - & 1.3666 & 30.94 & 10699.37 \\
\hline 150 & - & - & - & - & - & - & 0.4685 & 34.37 & 35398.11 \\
\hline
\end{tabular}




\section{RESULTS AND DISCUSSIONS}

Effects of both weight on bit (WOB), rotary speed (RPM), and the rock properties on rate of penetration at rotary speed of $1200 \mathrm{rpm}$ were discussed below:

\section{a) Effect of both WOB and Rotary Speed on Rate of Penetration:}

Effect of weight on bit (WOB) on the rate of penetration (ROP) in the three types of rocks is given in figures (2), (3) and (4). From these figures it is clear that, the increasing of the weight on bit (WOB) produces an increase in the rate of penetration (ROP) up to a maximum point. However, from the experimental data a further increase in weight on bit (WOB) causes little increase, or even a decrease in the rate of penetration (ROP) as in the case of drilling fresh limestone at $400 \mathrm{rpm}$.

The optimum load (WOB) is the weight which gives maximum value of the penetration rate (ROP) for rock drilling. From Fig. (2) For fresh limestone (rock No.1), at $60 \mathrm{Kg}$ (WOB) the ROP is 3.2 which the maximum value of ROP at rotary speed 400 $\mathrm{rpm}$. Where as at $120 \mathrm{Kg}$ (WOB) the ROP was $14.2 \mathrm{~cm} / \mathrm{min}$ at rotary speed of 1200 rpm. If we compare between ROP in the two cases ( at $400 \mathrm{rpm}$ and $1200 \mathrm{rpm}$ ) we find that the ROP at $1200 \mathrm{rpm}$ will be from 1-6 times more than that at $400 \mathrm{rpm}$.

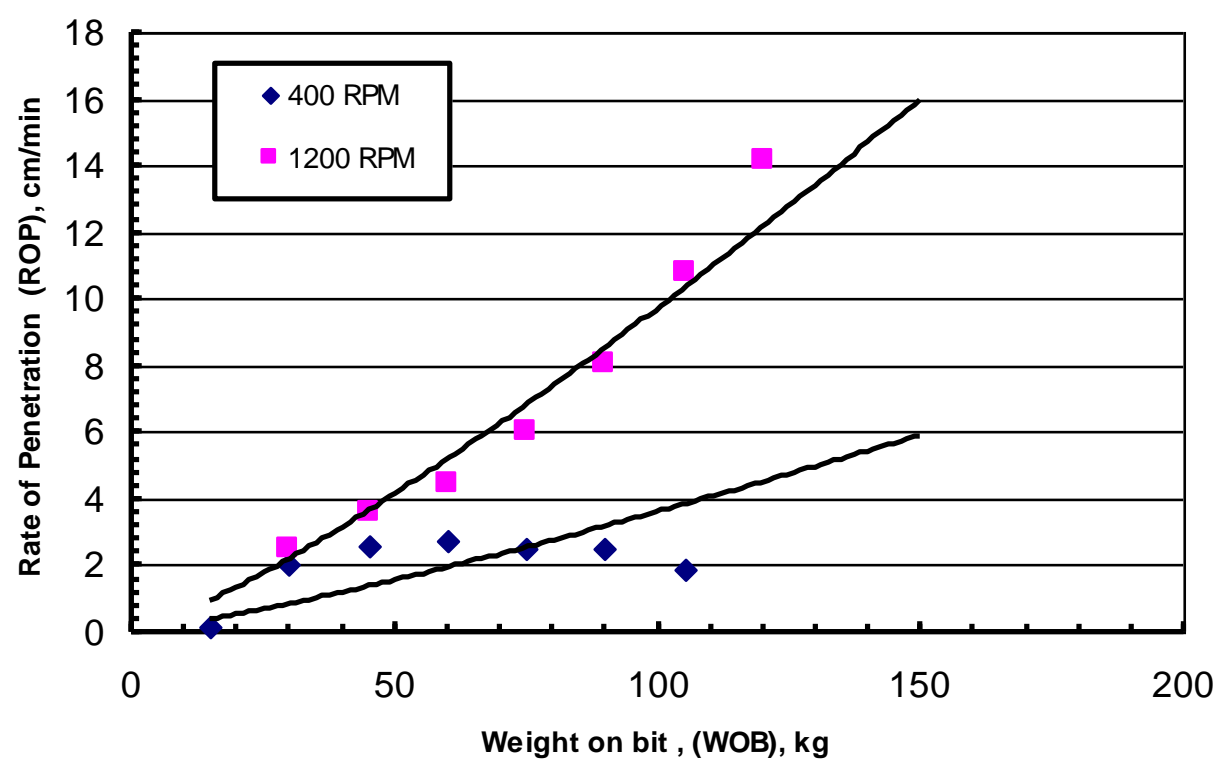

Fig. (2) Relation between (WOB) and (ROP) for Fresh Limestone (Rock No. 1) at rotary speed of 400 and 1200 RPM.

From Fig. (3) for bedded limestone (rock No. 2), the maximum value of ROP was $0.95 \mathrm{~cm} / \mathrm{min}$ at WOB $120 \mathrm{Kg}$. for rotary speed $400 \mathrm{rpm}$, the maximum value of ROP was $2.09 \mathrm{~cm} / \mathrm{min}$ at WOB $75 \mathrm{Kg}$ for rotary speed $1200 \mathrm{rpm}$. 


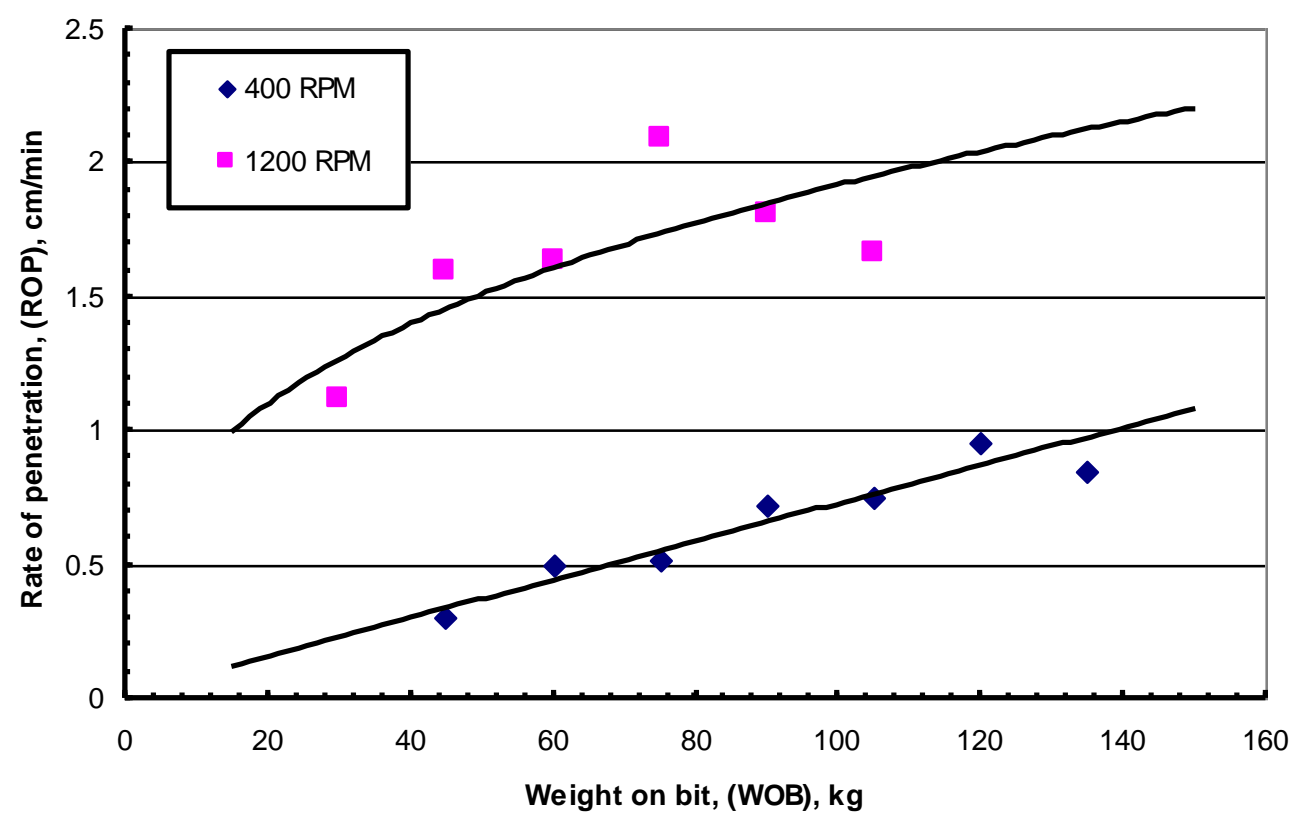

Fig. (3) Relation between (WOB) and (ROP) for Bedded limestone (Rock No. 2) at rotary speed of 400 and 1200 RPM.

If we compare between the two cases we will find that the ROP at 105 as an example for rotary speed of $400 \mathrm{rpm}$ was $0.75 \mathrm{~cm} / \mathrm{min}$ where as for rotary speed of $1200 \mathrm{ROP}$ was $\mathrm{rpm} 1.66 \mathrm{~cm} / \mathrm{min}$. The ROP is from (1-4) times more for $1200 \mathrm{rpm}$ than that for $400 \mathrm{rpm}$.

Figure (4) For non fresh limestone ( rock No. 3 ), the maximum value of ROP was $1.79 \mathrm{~cm} / \mathrm{min}$ at $\mathrm{WOB} 120 \mathrm{Kg}$ for the rotary speed $1200 \mathrm{rpm}$ where as the maximum value of ROP was $0.74 \mathrm{~cm} / \mathrm{min}$ at $120 \mathrm{Kg}$ for rotary speed of $400 \mathrm{rpm}$. This mean the ROP is about 2.5 times more at $1200 \mathrm{rpm}$ than that at $400 \mathrm{rpm}$ for the same WOB.

From the three figures ( 2,3 and 4$)$ we can concluded that increasing rotary speed from $400 \mathrm{rpm}$ to $1200 \mathrm{rpm}$ increase the rate of penetration for all rocks. The increasing in ROP was graduate from the less value in case of non - fresh limestone to the high value in case of fresh limestone and the ROP in case of bedded limestone was found to be in between. This reflects the effect of hardness on the ROP. The ROP proportional inversely with rock hardness. We can concluded at load of $105 \mathrm{Kg}$ WOB and $1200 \mathrm{rpm}$, the rate of penetration in fresh limestone is about 7and 14 times more than of the bedded and non fresh limestone respectively at 400 figures $(2,3,4)$ 


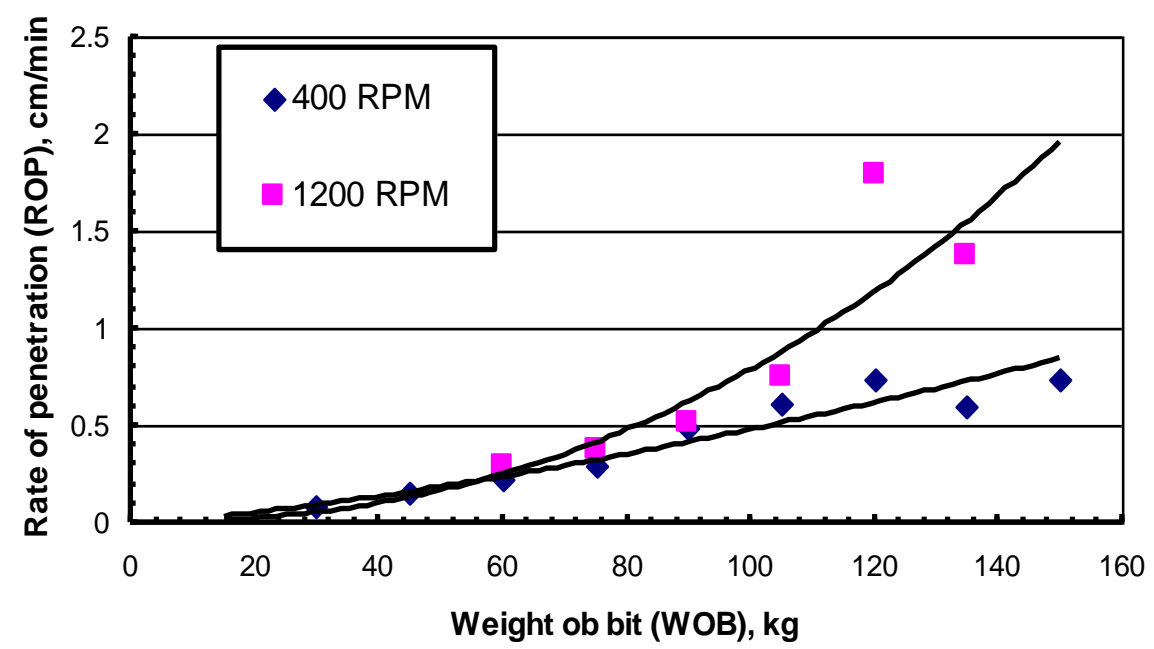

Fig. (4) Relation between (WOB) and (ROP) for Non-Fresh Limestone. (Rock No. 3) at rotary speed of 400 and 1200 RPM.

\section{b) Effect of WOB on Specific Energy at Different Rotary Speed:}

A very good indication of how well a bit performing in a particular rock formation is given by a study of the drilling specific energy. Specific energy (SE) may be defined, as the energy required for removing a unit volume of rock; it may use any consistent set of units [10,14, 15, 16, and 17]

From Fig.(5) it can be seen that the optimum WOB which give the lower value of specific energy is $30 \mathrm{~kg}$ for drilling in Fresh limestone at rotary speed of $400 \mathrm{rpm}$ whereas WOB of $120 \mathrm{~kg}$ is the optimum WOB when drilling with $1200 \mathrm{rpm}$.

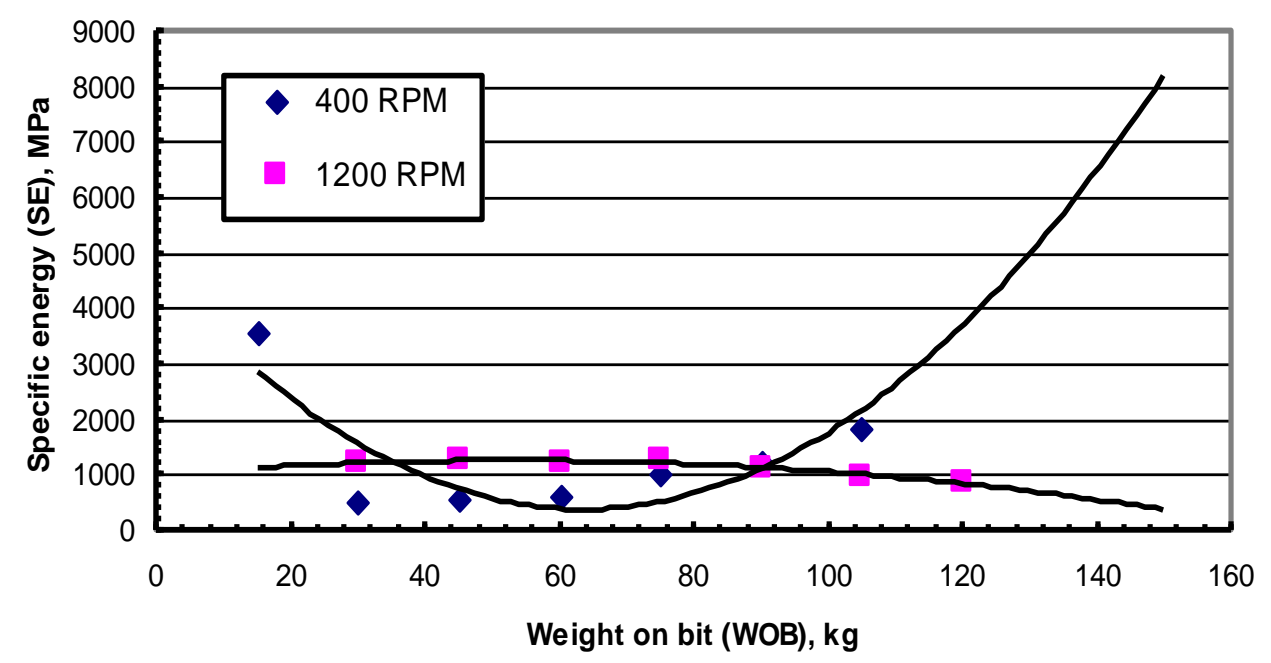

Fig. (5) Relation between (WOB) and (S.E) for Fresh Limestone (Rock No. 1) at rotary speed of 400 and 1200 RPM. 
From Fig. (6) it can be seen that the optimum WOB which give the lower value of specific energy is $60 \mathrm{~kg}$ for drilling in Bedded limestone at rotary speed of 400 rpm where as WOB of $30 \mathrm{~kg}$ is the optimum WOB when drilling with $1200 \mathrm{rpm}$ in Bedded limestone (Rock No. 2).

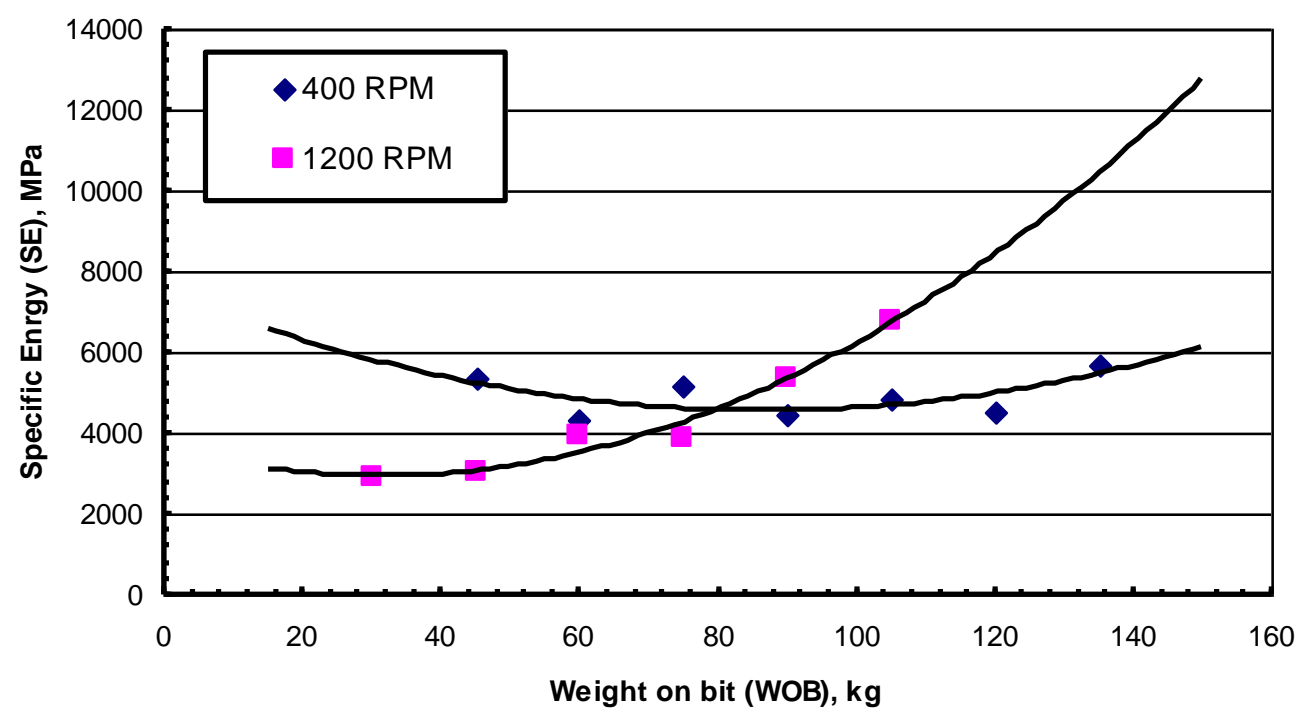

Fig. (6) Relation between (WOB) and (S.E) for Bedded Limestone (Rock No. 2) at rotary speed of 400 and 1200 RPM.

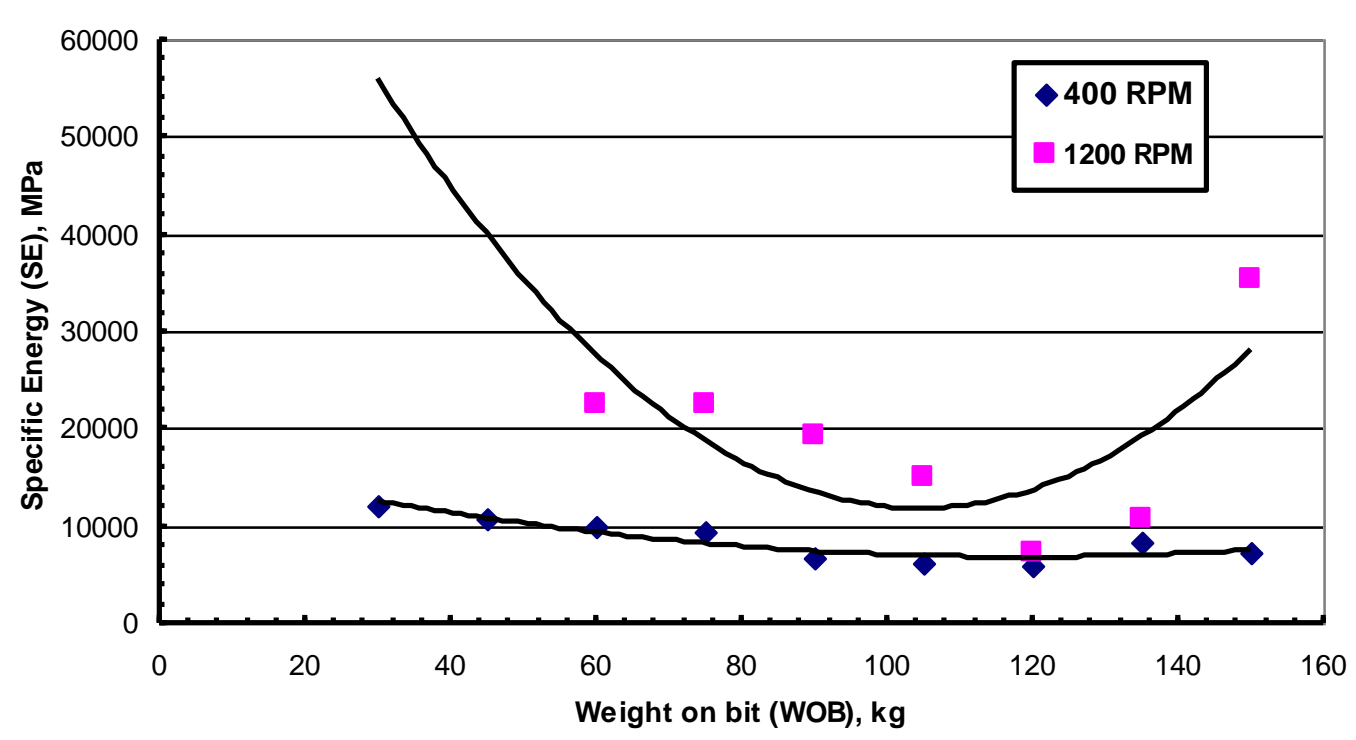

Fig. (7) Relation between (WOB) and (S.E) for Non-Fresh Limestone (Rock No. 3) at rotary speed of 400 and 1200 RPM. 
From Fig. (7) it can be seen that the optimum WOB which give the lower value of specific energy is $120 \mathrm{~kg}$ for drilling in Non-Fresh limestone at rotary speed of $400 \mathrm{rpm}$ and of $1200 \mathrm{rpm}$ in Non-Fresh limestone (Rock No. 3).

Figures 5, 6 and 7 show that at low WOB, SE increases for the three types of rock and increasing WOB is associated by decreasing in SE for a certain limits, then decreasing WOB increases SE. WOB that give the lower value of the SE is the optimum WOB. From the results it can be seen that the optimum WOB is $120 \mathrm{~kg}$ for drilling in Fresh limestone and $30 \mathrm{~kg}$ for drilling in Bedded limestone and $120 \mathrm{~kg}$ for drilling in Non-Fresh Limestone.

\section{c) Relation between (ROP) and (S.E).}

From fig (8) at rotary speed $400 \mathrm{rpm}$, it can be seen that SE is proportional inversely with ROP in all tested rocks, but Fresh limestone requires less SE than Bedded limestone and Bedded limestone requires less SE than Non-Fresh Limestone [5].

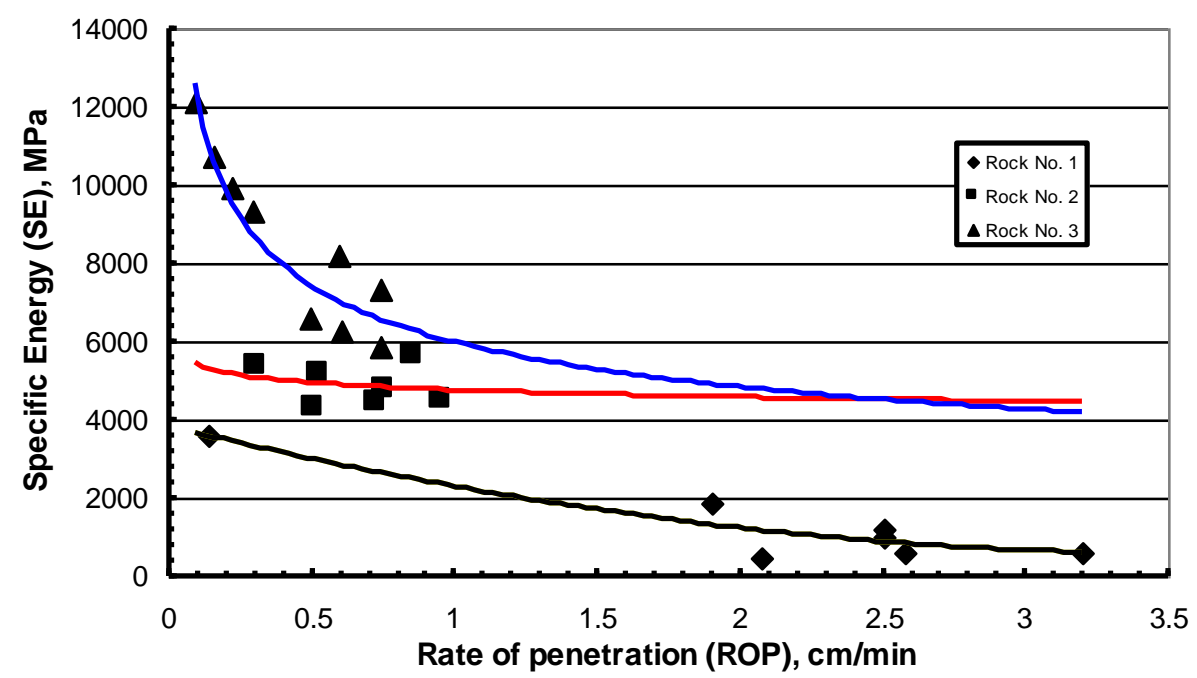

Fig. 8 Relationship between rate of penetration (ROP) and specific energy (SE) for the three rocks at 400 RPM.

Figures $(9,10$ and11) Show the relationships between rate of penetration and specific energy for fresh limestone (rock No. 1), bedded limestone (rock No. 2) and non-fresh limestone (rock No. 3) at $1200 \mathrm{rpm}$. It can be seen that SE is proportional inversely with ROP in fresh limestone and non-fresh limestone but it does not be found in case of bedded limestone that is because of bedding which is oriented parallel to drilling axis (Fig.10). 


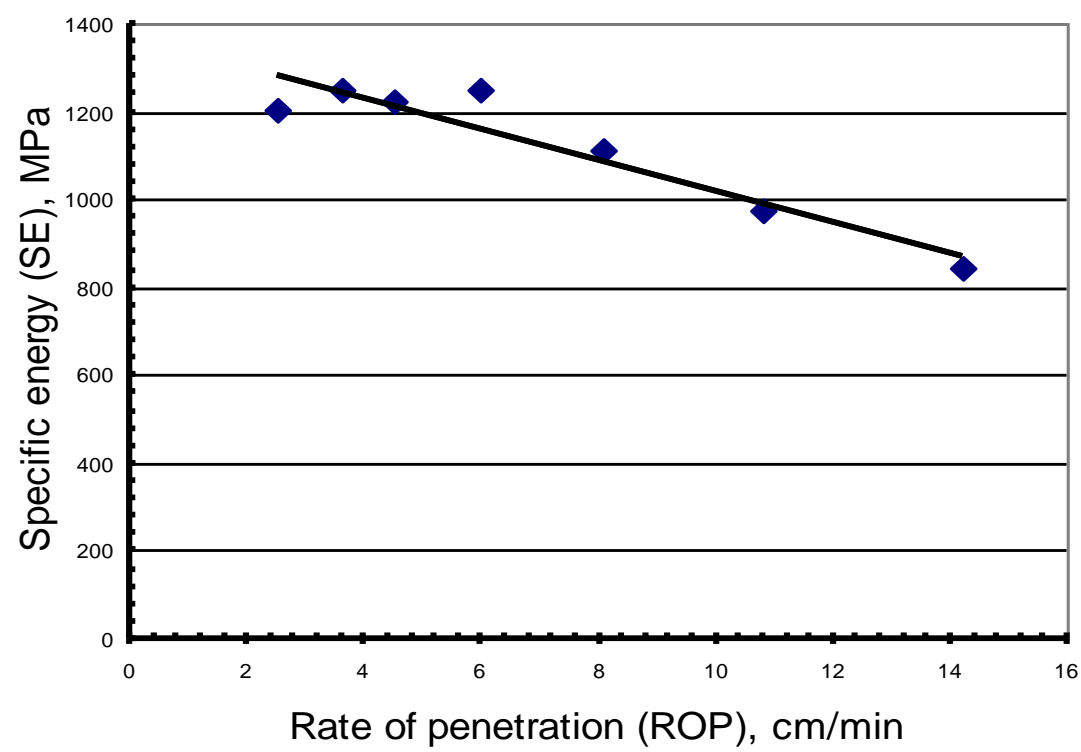

Fig. 9 Relationship between rate of penetration and specific energy for fresh limestone (rock No. 1) at $1200 \mathrm{rpm}$.

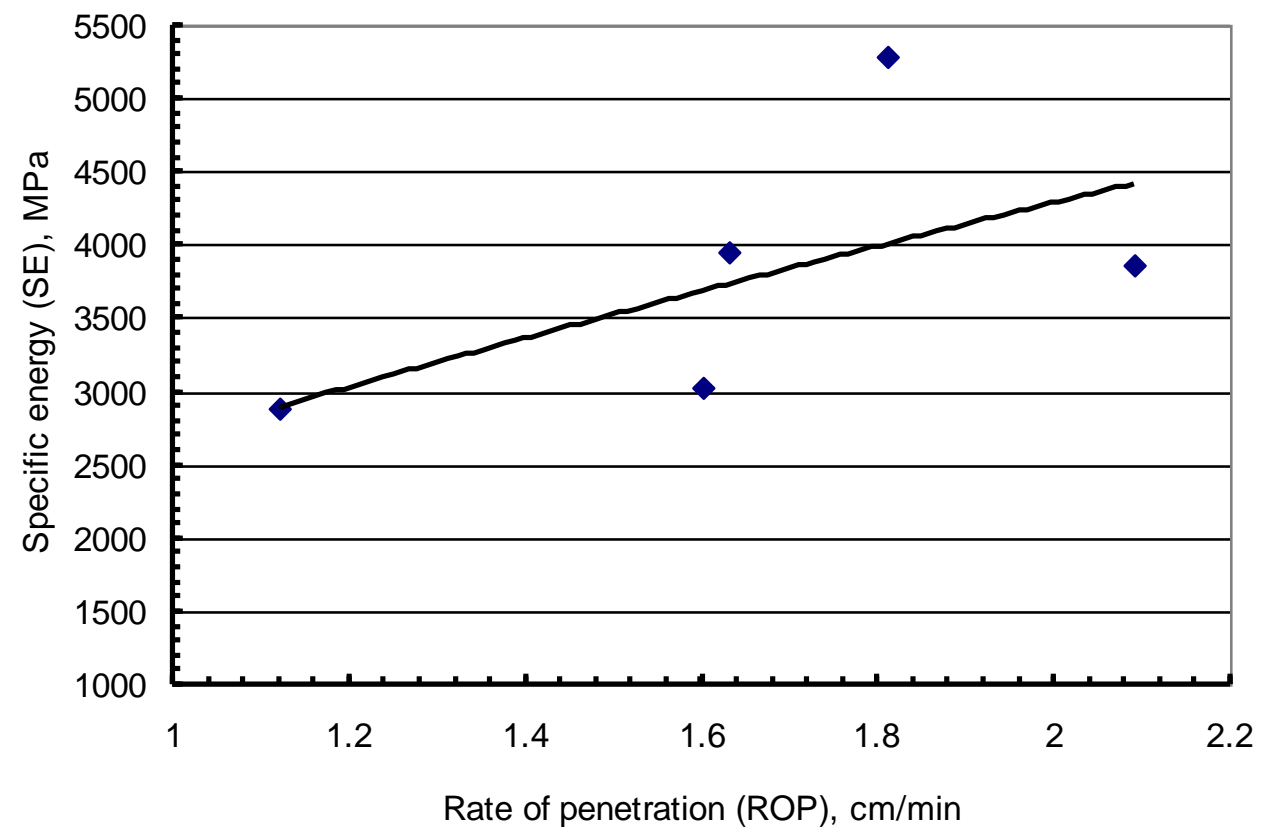

Fig. 10 Relationship between rate of penetration and specific energy for bedded limestone (rock No. 2) at $1200 \mathrm{rpm}$. 


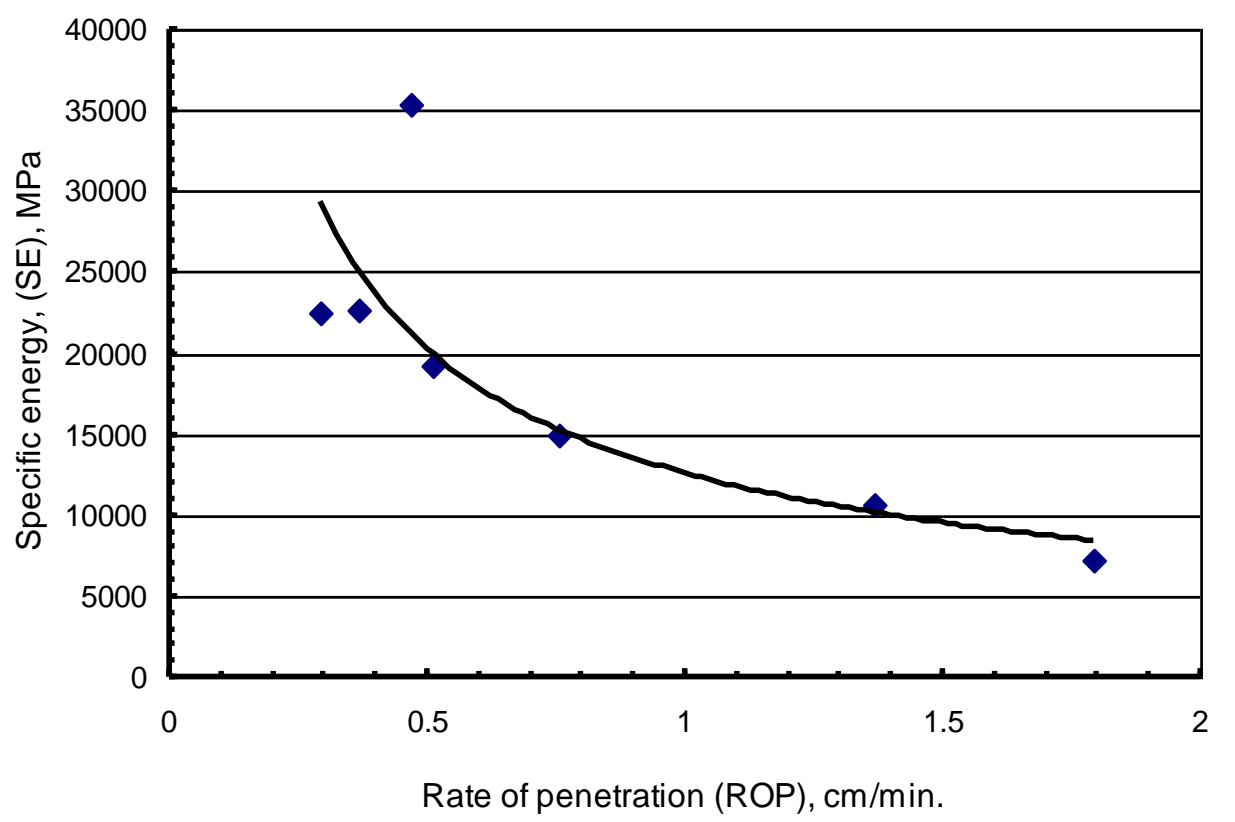

Fig. 11 Relationship between rate of penetration and specific energy for non-fresh limestone (rock No. 3) at $1200 \mathrm{rpm}$.

\section{d) Effect of Rock Properties on ROP at 400 and 1200 rpm}

Increasing the rotary speed from $400 \mathrm{rpm}$ to $1200 \mathrm{rpm}$ does not change the effect of geological parameters on the ROP. Fresh limestone has highest value of ROP because it contains the lowest iron oxide and quartz; on the other hand, Non-Fresh Limestone has the lowest value of ROP, because it contains the lowest percentage of iron oxides and quartz. By the same way we predict that Bedded limestone is lower than NonFresh Limestone in penetration rate, but, the experimental data show that it is higher than it, that is because of bedding which is oriented parallel to drilling axis.

There were a correlation between the porosity of the rock and technical parameters. Accordingly we found that Fresh limestone has the highest value of penetration rate and high value of porosity (12.87\%). Bedded limestone and non-fresh limestone having lower penetration rate and porosity $(9.06 \%, 6.083 \%)$ respectively than fresh limestone.

\section{CONCLUSION}

1- The ROP will be from ( 1-6 ), (1-4) and 2.5 times more at $1200 \mathrm{rpm}$ than that $400 \mathrm{rpm}$ for drilling in fresh limestone, bedded limestone and non-fresh limestone respectively.

2- We can concluded at load of $105 \mathrm{Kg}$ WOB and $1200 \mathrm{rpm}$ the rate of penetration in fresh limestone is about 7 and 14 times more than of the bedded and non fresh limestone at $400 \mathrm{rpm}$ respectively. 
3- At low WOB, SE increases for the three types of rock and increasing WOB is associated by decreasing in SE for a certain limits, then decreasing WOB increases SE. WOB that give the lower value of the SE is the optimum WOB. From the results, it 's found that the optimum WOB is $30 \mathrm{~kg}$ for drilling in fresh limestone and $60 \mathrm{~kg}$ for drilling in Bedded limestone and $120 \mathrm{~kg}$ for drilling in Non-Fresh Limestone for the two cases at 400 and $1200 \mathrm{rpm}$.

4- S.E is proportional inversely with ROP in all tested rocks, but Fresh limestone requires less S.E than Bedded limestone, and Bedded limestone requires less S.E than Non-Fresh Limestone. The lower value of S.E indicates the bit is more efficiency. To achieve a low S.E it is obviously advantageous to have as high a penetration rate as possible. To obtain ROP of $0.5 \mathrm{~cm} / \mathrm{min}$ as an example, the drilling machine needs S.E in Non-Fresh Limestone 3 times that for Fresh limestone and 2 times for Bedded limestone.

5- This study achieved the true of ROP proportional directly with porosity. Increasing of ROP in case of fresh limestone is associated by an increase in porosity $(12.87 \%)$ and vise versa. Decreasing of ROP in case of bedded and non-fresh limestone is associated by decrease in porosity $(9.06 \%$ and $6.08 \%)$ respectively.

\section{REFERENCES}

[1] THURO. K., " Drillability prediction - geological influences in hard rock drill and blast tunneling " Geol. Rundsch Vol. 86: pp 426-438. 1997.

[2] M. M. El-Biblawi, M. A. Sayed, M. T. Mohamed, and W. R. El-Rawy., " Some drilling parameters as a tool to predict different categories of rocks ",. Journal of engineering sciences, Assiut university, Vol. 35, No. 4, pp. 995-1008, July 2007

[3] Ersoy, A., and Waller, M. D., "Drilling detritus and the operating parameters of thermally stable PDC core bits", Int. J. Rock Mech. \& Min. Sci., Vol. 34, No. 7, Pp. 1109 - 1123, 1997.

[4] Kelessidis, V. p., Dalamarinis, P., "Monitoring drilling parameters allows optimization of drilling rates", International Multidisciplinary Scientific GeoConference \& EXPO. Modern Management of Mine Producing, Geology and Environmental Protection SGEM 2009, Albena, Bulgaria, June 14-19.

[5] Gamal. Y. Boghdady, "Mechanical and geological influences on drilling limestone rock at low rotary speed", Journal of Engineering Science, Faculty of Engineering, Assiut University, Vol. 38, No. 1, pp 259-270, January 2010.

[6] Sayed, M.A., "Relation between operating parameters and bit performance in diamond core drilling", 7th International Conference on Mining, Petroleum and Metallurgical Engineering, 10-12 February, Assiut, Egypt, 2001.

[7] SCHORMAIR N., THURO K. \& PLINNINGER R.J., "The influence of anisotropy on hard rock drilling and cutting" The geological society of London IAEG2006 paper Number 491.

[8] THURO, K.,\& PLINNINGER R.J.," Hard rock tunnel boring, cutting and blasting: rock parameters for excavatability, In: Proceedings of the 10th ISRM International congress on Rock Mechanics, Johannesburg South Africa, 8-12, Septemper2003, 1227-1234. 
[9] Roberts, T. S, and Schen, A. E, "Optimization of PDC drill bit performance utilizing high speed, real-time downhole data acguired under cooperative research and development agreement" SPE/IADC Drilling Conference held in Amsterdam, The Netherlands, 23-25 February 2005.

[10] Akin S. and Karpuz C., "Estimating drilling parameters for diamond bit drilling operations using artificial neural networks", International Journal of Geomechanics, vol. 8, No. 1, February 1, 2008.

[11] M. M. Youssef., E. R. Philobbos and W. W. Bishara. , " Geological studies on the sediment rocks along the Assiut - Kharga road " Workshop on Geoindications and their applications in arid region, Sept. 2003 Assiut university

[12] Savic, L., Ristovic, I and Savic K., "Correlation relationship between drilling bit endurance and the most important parameters of the rock mass"RMZMaterials and Geoenvironmental, Vol. 1, pp. 54-59, 2009

[13] Imbaby, S.S., "Study of some factors affecting the drillability of rocks," M.Sc thesis, Faculty of Engineering, Assiut University, 1980.

[14] Chugh, C.P., "High technology in drilling and and exploration " , A. A. Balkema, Rotterdam, 1992

[15] Rabia, H., "Specific energy as a criterion for bit selection ", Journal of Petroleum Technology, July 1985.

[16] Rowsell, P. T. and Waller, M. D., " Automatic optimization of rotary drilling parameters", 99, May - August, 1990.

[17] Teale, R., " The concept of specific energy in rock drilling ",. Int. J. Rock Mech. Min. Sci. 2, pp. 57-73, 1965.

\section{تحسين اداة الة الحفر الماسية باستخدام سرعات عالية للحفر في صخور الحجر}

\section{الجيري.}

العوامل الرئيسية المطلوب تحديدها خلال عمليات الحفر هى معايير نتثغيل الة الحفر وخصائص الصخور التي

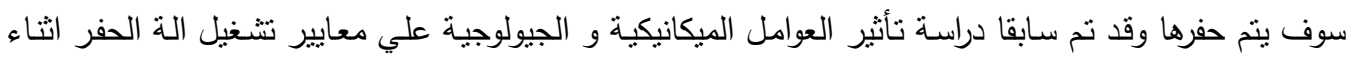
الحفر في صخور الحجر الجيري تحت سرعة منخفضة تعادل 400 لفة / دقيقة.

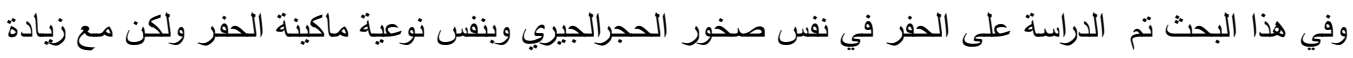
سرعة الحفر الى 1200 لفة / دقيقة بواسطة ماكينة الحفر المعطلية ذات قواطع الماس وتحت تأثير اوزان مختلفة

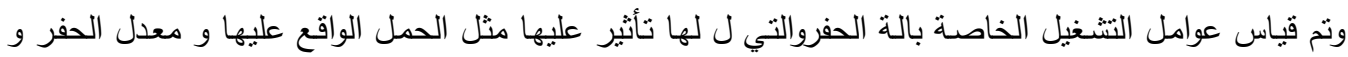

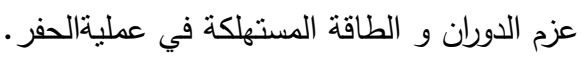
ومن خلال الدراسة تم عمل علاقة بين معدل الحفر والطاقة المستهلكة في الحفر و تم مقارنة هذه النتائج تحت

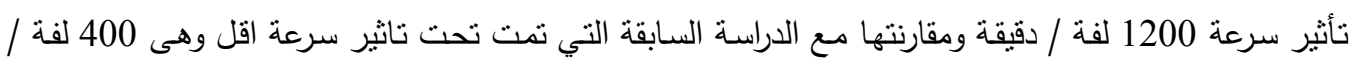

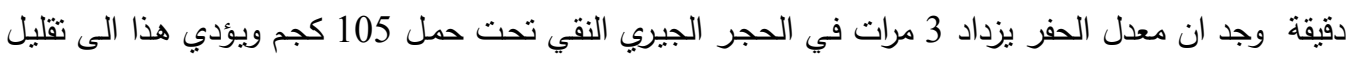

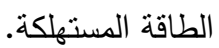
من الدراسة وجد انة عند معدل 0.5 سم/دقيقة مثنلا أو كمثال نجد إن الطاقة المستهلكة في الحفر في الحجر الجيري الغير نقي تعادل 3 مرات قدرها في الحجر الجيري النقي وتعادل مرتين في الحجر الجيري الطباقي . 